\title{
Association of Age With Tumor Grade in Patients With Digestive Tumors: A Study Based on US SEER Registry
}

Yange Zhang ( $\square$ zhangyangeplastic@126.com )

Department of Plastic and Burns, West China Hospital, Sichuan University, Chengdu 610041, Sichuan Province, China

Wei Li

Sichuan University

Research article

Keywords: Age, tumor grade, association, prognosis

Posted Date: December 1st, 2020

DOI: https://doi.org/10.21203/rs.3.rs-115854/v1

License: (c) (i) This work is licensed under a Creative Commons Attribution 4.0 International License. Read Full License 


\section{Abstract}

Background: Previous studies have not demonstrated an independent association of age and tumor grade. In this study, we aimed to explore the relationship between age and tumor grade (differentiation) in patients with digestive tumors.

Methods: Surveillance, Epidemiology and End Results (SEER) 18 registry database for 1973 through 2015 was retrieved for the present study. Both piecewise and non-piecewise linear regression model were utilized to examine the relationship between age and tumor grade.

Results: The present study included a total of 938,145 patients with 13 types of primary malignancies of the digestive system. In non-piecewise regression analyses, older age was associated with higher tumor grades in patients with esophageal squamous cell carcinoma $(P<0.0001)$ and anal squamous cell carcinoma $(P<0.0001)$. In contrast, older age was related to lower tumor grades in patients with esophageal adenocarcinoma $(P=0.0177)$, gastric adenocarcinoma $(P<0.0001)$, pancreatic adenocarcinoma $(P<0.0001)$ and rectal adenocarcinoma $(P<$ 0.0001). In piecewise regression analyses, positive associations of age and tumor grade were only observed in specific age groups in some types of tumor, e.g., anal adenocarcinoma (> 66 years), gallbladder adenocarcinoma (> 49 years), pancreatic adenocarcinoma (> 56 years), hepatocellular carcinoma (35-90 years), rectal adenocarcinoma ( $<59$ years in White; $<52$ years in Non-White) and anal squamous cell carcinoma $(<51$ years in White; $<58$ years in Non-White). Patients with well-differentiated tumors had better long-term prognoses compared to those with poorly-differentiated tumors (all $\mathrm{P}<0.05$ ).

Conclusion: The patterns of relationship between age and tumor grade were different in patients with different types of digestive tumor, which may be a reflection of the distinct molecular subtypes of these tumors.

\section{Introduction}

Pathologic examination determines the grade (degree of differentiation) of the tumor. The grade measures how closely the tumor cells resemble the parent tissue (organ of origin).[1] In some types of solid tumors, traditionally, the pathologists have adopted a four-grade system (well-, moderate-, poorly- and un-differentiated) to classify the tumors.[2] Well-differentiated tumor cells closely resemble the tissue from the organ of origin. Poorly-differentiated and un-differentiated tumor cells are disorganized and abnormal looking. They bear little (poorly-differentiated) or no (un-differentiated) resemblance to the tissue from the organ of origin. These similarities/differences are based on cytology, nuclear (or nucleolar) features, pattern (architecture), or a combination of these elements.

Tumor grade represents a gestalt of all subtle changes in molecular level, reflecting proliferation and aggressiveness.[3-8] The distribution of tumor grade were different between younger and older patients in some types of tumor.[9-12] However, previous studies did not illustrate the independent association between age and tumor grade. In the present study, we aimed to explore the relationship between age and tumor grade in 13 types of solid tumors of the digestive system.

\section{Patients And Methods}

Patient Selection 
Surveillance, Epidemiology and End Results (SEER) 18 registry database for 1973 through 2015 was retrieved for the present study. The SEER program collects data regarding cancer incidence, patient demographics, tumor parameters, patient treatment and survival from 18 population-based cancer registries, covering approximately $28 \%$ of the US population (seer.cancer.gov/about/overview.html). Primary cancer site and histology were coded based on the third edition of the International Classification of Diseases for Oncology (ICD-0-3) in SEER 18. We identified 938,145 patients with 13 types of primary malignancies of the digestive system according to ICD-0-3 site code and histologic code from the SEER database (Supplementary Table 1). The 13 types of tumors included esophageal adenocarcinoma, esophageal squamous cell carcinoma, gastric adenocarcinoma, hepatocellular carcinoma, intrahepatic cholangiocarcinoma, extrahepatic cholangiocarcinoma, carcinoma of the gallbladder, pancreatic adenocarcinoma, small bowel adenocarcinoma, colon adenocarcinoma, rectal adenocarcinoma, anal adenocarcinoma and anal squamous cell carcinoma. We excluded patients without histologic diagnosis and patients without complete survival data and follow-up information.

We extracted demographic and clinicopathological data, including gender, age, race and tumor grade (differentiation) from SEER database. Race was divided into white, black and others. Tumor grade was divided into grade I (well differentiated), grade II (moderately differentiated), grade III (poorly differentiated) and grade IV (undifferentiated).

\section{Statistical analysis}

Multivariable linear regression analyses were used to examine the association between age and tumor grade. In all regression models, multivariable adjustments were made by including age, gender and race. Then we explored the relationship between age and tumor grade by the smoothing plot, with an adjustment for potential confounders. We further applied a piecewise linear regression model to examine the threshold effect of age on tumor grade according to the smoothing plot. Model 1 and model 2 were the non-piecewise and piecewise linear regression models, respectively. To evaluate whether there was interaction with gender, race and tumor grade on the one hand and age on the other hand, we evaluated the interaction terms ( e.g. age x gender) in the multivariable models. In case of $p<0.05$, stratified analyses were performed. In this study, patients with colonic adenocarcinoma, rectal adenocarcinoma, hepatocellular carcinoma and anal squamous cell carcinoma were performed subgroup analyses based on sex and race (interaction $P$ values $<0.05$ ). The survival curves were determined by the KaplanMeier method and compared by the log-rank test. In survival analyses, grade 1 and 2 were grouped into welldifferentiated and grade 3 and 4 were grouped into poorly-differentiated. All analyses were performed by $R$ (http://www.R-project.org) and EmpowerStats software (www.empowerstats.com, X\&Y solutions, Inc. Boston MA).

\section{Results}

\section{Patient characteristics}

The present study included a total of 938,145 patients with 13 types of primary malignancies of the digestive system. The clinicopathological features of the 13 types of tumor were shown in Table 1. Age were presented as mean \pm standard deviance. Sex, race and tumor grade in different types of tumor were shown in numbers. In Fig. 1, age was divided into 10 groups and the number of patients were shown by sex. 
Table 1

Basic characteristics of the included patients between the year of 1973 and 2015.

\begin{tabular}{|c|c|c|c|c|}
\hline & $\begin{array}{l}\text { Age } \\
\text { (years) }\end{array}$ & $\operatorname{Sex}(M / F)$ & $\begin{array}{l}\text { Race } \\
\text { (White/Black/other) }\end{array}$ & $\begin{array}{l}\text { Tumor grade (Grade } \\
\text { I/II/III/IV) }\end{array}$ \\
\hline $\begin{array}{l}\text { Esophageal } \\
\text { squamous cell } \\
\text { carcinoma }\end{array}$ & $\begin{array}{l}66.9 \pm \\
11.3\end{array}$ & $22662 / 11802$ & $22485 / 9060 / 2919$ & 1908/12430/12253/476 \\
\hline $\begin{array}{l}\text { Esophageal } \\
\text { adenocarcinoma }\end{array}$ & $\begin{array}{l}66.7 \pm \\
12.0\end{array}$ & $31944 / 5299$ & $35394 / 989 / 849$ & 2051/12381/15599/529 \\
\hline $\begin{array}{l}\text { Gastric } \\
\text { adenocarcinoma }\end{array}$ & $\begin{array}{l}68.9 \pm \\
12.4\end{array}$ & $52402 / 26205$ & $57039 / 9665 / 11752 / 151$ & 5518/27223/43958/1908 \\
\hline $\begin{array}{l}\text { Adenocarcinoma of } \\
\text { small intestine }\end{array}$ & $\begin{array}{l}66.9 \pm \\
14.0\end{array}$ & $5183 / 4392$ & $7431 / 1560 / 584$ & 1094/4995/3350/136 \\
\hline $\begin{array}{l}\text { Colonic } \\
\text { adenocarcinoma }\end{array}$ & $\begin{array}{l}69.3 \pm \\
13.0\end{array}$ & $251686 / 264177$ & $424466 / 54919 / 36478$ & $62614 / 349988 / 95387 / 7874$ \\
\hline $\begin{array}{l}\text { Rectal } \\
\text { adenocarcinoma }\end{array}$ & $\begin{array}{l}65.7 \pm \\
13.3\end{array}$ & $78909 / 55447$ & $112570 / 10307 / 11479$ & $15690 / 97384 / 20025 / 1257$ \\
\hline $\begin{array}{l}\text { Anal } \\
\text { adenocarcinoma }\end{array}$ & $\begin{array}{l}68.4 \pm \\
14.1\end{array}$ & $1594 / 1424$ & $2422 / 381 / 215$ & $449 / 1874 / 650 / 45$ \\
\hline $\begin{array}{l}\text { Anal squamous cell } \\
\text { carcinoma }\end{array}$ & $\begin{array}{l}60.8 \pm \\
13.4\end{array}$ & $5711 / 9631$ & $13424 / 1551 / 367$ & 2385/7246/5533/178 \\
\hline $\begin{array}{l}\text { Hepatocellular } \\
\text { carcinoma }\end{array}$ & $\begin{array}{l}64.1 \pm \\
12.3\end{array}$ & $24907 / 8281$ & $22230 / 4283 / 6554$ & 11103/13623/7617/845 \\
\hline $\begin{array}{l}\text { Intrahepatic } \\
\text { cholangiocarcinoma }\end{array}$ & $\begin{array}{l}64.6 \pm \\
12.4\end{array}$ & $3229 / 3032$ & 4922/486/853 & $805 / 2764 / 2582 / 110$ \\
\hline $\begin{array}{l}\text { Extrahepatic } \\
\text { cholangiocarcinoma }\end{array}$ & $\begin{array}{l}68.3 \pm \\
11.8\end{array}$ & 2392/1884 & $3458 / 260 / 558$ & $921 / 1934 / 1364 / 57$ \\
\hline $\begin{array}{l}\text { Gallbladder } \\
\text { adenocarcinoma }\end{array}$ & $\begin{array}{l}69.9 \pm \\
12.5\end{array}$ & $3602 / 9131$ & $10115 / 1235 / 1383$ & $2166 / 5364 / 4963 / 240$ \\
\hline $\begin{array}{l}\text { Pancreatic } \\
\text { adenocarcinoma }\end{array}$ & $\begin{array}{l}67.6 \pm \\
11.4\end{array}$ & $27136 / 26083$ & $43448 / 6078 / 3693$ & 7398/21602/23055/1164 \\
\hline
\end{tabular}

\section{Association of age and tumor grade in the non-piecewise models}

As shown in Tables 2 and 3, the effect values $(\beta)$ of non-piecewise multivariable linear regression analyses were shown in model 1. Older patients with esophageal squamous cell carcinoma $(P<0.0001)$ and anal squamous cell carcinoma $(P<0.0001)$ had higher tumor grades compared to younger patients. In addition, older age was also positively associated with higher tumor grades in the female $(P<0.0001)$ and White $(P<0.0001)$ patients with colonic adenocarcinoma. In contrast, older patients with esophageal adenocarcinoma $(P=0.0177)$, gastric adenocarcinoma $(P<0.0001)$, pancreatic adenocarcinoma $(P<0.0001)$ and rectal adenocarcinoma $(P<0.0001)$ had lower tumor grades. In stratified analyses, older age was negatively associated with tumor grade in male $(\mathrm{P}<$ $0.0001)$ and non-White $(P<0.0001)$ patients with colonic adenocarcinoma, and in male patients with hepatocellular carcinoma $(\mathrm{P}<0.0001)$. 
Table 2

Association between patient age and tumor grade in piecewise and non-piecewise regression analyses.

\begin{tabular}{|c|c|c|c|}
\hline & \multirow[t]{2}{*}{ Model 1} & \multicolumn{2}{|l|}{ Model 2} \\
\hline & & $<$ threshold value & $\geq$ threshold value \\
\hline $\begin{array}{l}\text { Esophageal squamous cell } \\
\text { carcinoma }\end{array}$ & $\begin{array}{l}0.002(0.001,0.003)< \\
0.0001\end{array}$ & / & / \\
\hline $\begin{array}{l}\text { Esophageal } \\
\text { adenocarcinoma* }\end{array}$ & $\begin{array}{l}-0.001(-0.001,-0.000) \\
0.0177\end{array}$ & $\begin{array}{l}0.005(0.001,0.009) \\
0.0104\end{array}$ & $\begin{array}{l}-0.001(-0.002,-0.001) \\
0.0006\end{array}$ \\
\hline Gastric adenocarcinoma & $\begin{array}{l}-0.004(-0.005,-0.004)< \\
0.0001\end{array}$ & / & / \\
\hline $\begin{array}{l}\text { Adenocarcinoma of small } \\
\text { intestine }{ }^{\star \star}\end{array}$ & $\begin{array}{l}-0.001(-0.001,0.000) \\
0.3144\end{array}$ & $\begin{array}{l}0.002(-0.001,0.005) \\
0.1872\end{array}$ & $\begin{array}{l}-0.001(-0.003,0.000) \\
0.0501\end{array}$ \\
\hline Anal adenocarcinoma*** & $\begin{array}{l}0.001(-0.001,0.003) \\
0.2295\end{array}$ & $\begin{array}{l}-0.003(-0.006,0.001) \\
0.1368\end{array}$ & $\begin{array}{l}0.004(0.001,0.008) \\
0.0076\end{array}$ \\
\hline $\begin{array}{l}\text { Intrahepatic } \\
\text { cholangiocarcinoma }\end{array}$ & $\begin{array}{l}0.001(-0.001,0.002) \\
0.3740\end{array}$ & / & / \\
\hline $\begin{array}{l}\text { Extrahepatic } \\
\text { cholangiocarcinoma }\end{array}$ & $\begin{array}{l}0.000(-0.002,0.002) \\
0.8835\end{array}$ & / & / \\
\hline $\begin{array}{l}\text { Gallbladder } \\
\text { adenocarcinomat }\end{array}$ & $\begin{array}{l}-0.001(-0.002,0.000) \\
0.1581\end{array}$ & $\begin{array}{l}0.006(-0.001,0.013) \\
0.0840\end{array}$ & $\begin{array}{l}-0.001(-0.003,-0.000) \\
0.0287\end{array}$ \\
\hline Pancreatic adenocarcinoma & $\begin{array}{l}-0.001(-0.002,-0.000) \\
0.0003\end{array}$ & $\begin{array}{l}0.001(-0.001,0.003) \\
0.1603\end{array}$ & $\begin{array}{l}-0.002(-0.002,-0.001)< \\
0.0001\end{array}$ \\
\hline \multicolumn{4}{|c|}{$\begin{array}{l}\text { Data was shown as beta }(95 \% \mathrm{Cl}) \text { P-value. Both model } 1 \text { and model } 2 \text { were adjusted for sex and race. }{ }^{*} \\
\text { Threshold value for esophageal adenocarcinoma is } 48 \text { years. } \\
\text { intestine is } 56 \text { years. Threshold value for adenocarcinoma of smal } \\
\text { gallbladder adenocarcinoma is } 49 \text { years. for anal adenocarcinoma is } 66 \text { years. Threshold value for pancreatic adenocarcinoma value for } 56 \text { years. }\end{array}$} \\
\hline
\end{tabular}


Table 3

Association of age and tumor grade in stratified analyses based on sex and race.

Tumor type

P for

interaction

Colonic adenocarcinoma

\begin{tabular}{|c|c|c|c|}
\hline & Female & Male & \\
\hline Model 1 & $\begin{array}{l}0.001(0.001,0.002)< \\
0.0001\end{array}$ & $\begin{array}{l}-0.001(-0.001,-0.001) \\
<0.0001\end{array}$ & $<0.0001$ \\
\hline Model 2 (< 56 years) & $\begin{array}{l}-0.004(-0.004,-0.003) \\
<0.0001\end{array}$ & $\begin{array}{l}-0.008(-0.008,-0.007) \\
<0.0001\end{array}$ & \\
\hline \multirow[t]{2}{*}{ Model 2 ( $\geq 56$ years) } & $\begin{array}{l}0.003(0.003,0.003)< \\
0.0001\end{array}$ & $\begin{array}{l}0.001(0.000,0.001)< \\
0.0001\end{array}$ & \\
\hline & White & Non-white & $<0.0001$ \\
\hline Model 1 & $\begin{array}{l}0.000(0.000,0.001)< \\
0.0001\end{array}$ & $\begin{array}{l}-0.001(-0.001,-0.001) \\
<0.0001\end{array}$ & \\
\hline $\begin{array}{l}\text { Model } 2(<57 \text { years in White; }<54 \text { years in } \\
\text { Non-White) }\end{array}$ & $\begin{array}{l}-0.005(-0.006,-0.005) \\
<0.0001\end{array}$ & $\begin{array}{l}-0.007(-0.008,-0.006) \\
<0.0001\end{array}$ & \\
\hline $\begin{array}{l}\text { Model } 2(\geq 57 \text { years in White; } \geq 54 \text { years } \\
\text { in Non-White) }\end{array}$ & $\begin{array}{l}0.002(0.002,0.002)< \\
0.0001\end{array}$ & $\begin{array}{l}0.001(0.000,0.001)< \\
0.0001\end{array}$ & \\
\hline
\end{tabular}

Rectal adenocarcinoma

\begin{tabular}{lll} 
& White & \multicolumn{1}{c}{$\begin{array}{l}\text { Non-white } \\
\text { Model } 1\end{array}$} \\
$\begin{array}{lll}-0.001(-0.001,-0.001) \\
<0.0001\end{array}$ & $\begin{array}{l}-0.002(-0.002,-0.001) \\
<0.0001\end{array}$ \\
$\begin{array}{l}\text { Model 2 }<59 \text { years in White; }<52 \text { years in } \\
\text { Non-White })\end{array}$ & $\begin{array}{l}-0.003(-0.004,-0.003) \\
<0.0001\end{array}$ & $\begin{array}{l}-0.007(-0.009,-0.005) \\
<0.0001\end{array}$ \\
$\begin{array}{l}\text { Model 2 } \geq 59 \text { years in White; } \geq 52 \text { years } \\
\text { in Non-White) }\end{array}$ & $\begin{array}{l}0.000(-0.000,0.000) \\
0.7461\end{array}$ & $\begin{array}{l}-0.000(-0.001,0.000) \\
0.3199\end{array}$
\end{tabular}

Hepatocellular carcinoma

\begin{tabular}{|c|c|c|c|}
\hline & Female & Male & 0.0010 \\
\hline Model 1 & $\begin{array}{l}-0.001(-0.002,0.000) \\
0.1784\end{array}$ & $\begin{array}{l}-0.003(-0.004,-0.002) \\
<0.0001\end{array}$ & \\
\hline Model 2 (< 35 years) & $\begin{array}{l}0.006(-0.003,0.016) \\
0.1996\end{array}$ & $\begin{array}{l}-0.001(-0.008,0.006) \\
0.7778\end{array}$ & \\
\hline Model 2 (35-90 years) & $\begin{array}{l}-0.002(-0.003,-0.000) \\
0.0231\end{array}$ & $\begin{array}{l}-0.003(-0.004,-0.002) \\
<0.0001\end{array}$ & \\
\hline \multirow[t]{2}{*}{ Model 2 ( $\geq 90$ year) } & $\begin{array}{l}0.002(-0.102,0.105) \\
0.9744\end{array}$ & $\begin{array}{l}0.063(-0.055,0.181) \\
0.2980\end{array}$ & \\
\hline & White & Non-white & $<0.0001$ \\
\hline Model 1 & $\begin{array}{l}-0.001(-0.002,-0.000) \\
0.0352\end{array}$ & $\begin{array}{l}-0.006(-0.007,-0.004) \\
<0.0001\end{array}$ & \\
\hline
\end{tabular}




\begin{tabular}{|c|c|c|c|}
\hline \multicolumn{3}{|l|}{ Tumor type } & \multirow[t]{2}{*}{$\begin{array}{l}P \text { for } \\
\text { interaction }\end{array}$} \\
\hline $\begin{array}{l}\text { Model } 2(<55 \text { years in White; }<35 \text { years in } \\
\text { Non-White) }\end{array}$ & $\begin{array}{l}-0.012(-0.015,-0.009) \\
<0.0001\end{array}$ & $\begin{array}{l}0.004(-0.003,0.010) \\
0.2807\end{array}$ & \\
\hline $\begin{array}{l}\text { Model } 2 \text { ( } \geq 55 \text { years in White; } \geq 35 \text { years } \\
\text { in Non-White) }\end{array}$ & $\begin{array}{l}-0.001(-0.002,-0.000) \\
0.0137\end{array}$ & $\begin{array}{l}-0.003(-0.004,-0.001) \\
0.0061\end{array}$ & \\
\hline \multicolumn{4}{|l|}{ Anal squamous cell carcinoma } \\
\hline & White & Non-white & $<0.001$ \\
\hline Model 1 & $\begin{array}{l}0.003(0.002,0.004)< \\
0.0001\end{array}$ & $\begin{array}{l}0.008(0.006,0.011)< \\
0.0001\end{array}$ & \\
\hline $\begin{array}{l}\text { Model } 2(<51 \text { years in White; }<58 \text { years in } \\
\text { Non-White) }\end{array}$ & $\begin{array}{l}0.016(0.012,0.020)< \\
0.0001\end{array}$ & $\begin{array}{l}0.014(0.009,0.019)< \\
0.0001\end{array}$ & \\
\hline $\begin{array}{l}\text { Model } 2 \text { ( } \geq 51 \text { years in White; } \geq 58 \text { years } \\
\text { in Non-White) }\end{array}$ & $\begin{array}{l}0.001(-0.001,0.002) \\
0.2822\end{array}$ & $\begin{array}{l}0.002(-0.002,0.007) \\
0.2874\end{array}$ & \\
\hline
\end{tabular}

Age was not associated with tumor grade in patients with adenocarcinoma of small intestine $(P=0.3144)$, anal adenocarcinoma $(P=0.2295)$, intrahepatic cholangiocarcinoma $(P=0.3740)$, extrahepatic cholangiocarcinoma ( $P$ $=0.8835)$ and gallbladder adenocarcinoma $(P=0.1581)$.

\section{Association of age and tumor grade in the piecewise models}

Except for four types of tumor (esophageal squamous cell carcinoma, gastric adenocarcinoma, intrahepatic cholangiocarcinoma and extrahepatic cholangiocarcinoma), threshold values were found in the other types of tumors by the smoothing plot adjusted by confounding factors (sex and race). In model 2, we presented the results of the piecewise regression analyses. In Figs. 2 and 3, the smoothing plot showed that the effect of age on tumor grade was distinct in different age groups. Positive associations of age and tumor grade were only observed in specific ages in some types of tumor such as anal ( $>66$ years), gallbladder ( $>49$ years), pancreatic adenocarcinoma ( $>56$ years), hepatocellular carcinoma (35-90 years), rectal adenocarcinoma ( $<59$ years in White; $<52$ years in Non-White) and anal squamous cell carcinoma ( $<51$ years in White; $<58$ years in Non-White). Notably, for some types of tumor (e.g., colonic adenocarcinoma and esophageal adenocarcinoma), the significance was not changed in different age groups, while the effect size of age on tumor grade was different.

\section{Survival analyses based on tumor grade}

To explore the prognostic significance of tumor grade in these types of tumor, we performed survival analyses based on tumor grade. As shown in Fig. 4 (tumors in the hepatobiliary system) and Fig. 5, the results showed that patients with well-differentiated tumors had better long-term prognoses compared to those with poorlydifferentiated tumors (all $\mathrm{P}<0.05$ ). The results were consistent in all types of tumor.

\section{Discussion}

Previous publications have not demonstrated the association of age and tumor grade. In this large cross-sectional study, we explored the relationship of age and tumor grade in 13 types of digestive tumors. In the multivariable 
regression models, both positive and negative associations were observed in different tumor types. Interestingly, in patients with squamous cell carcinoma, older patients tended to have higher tumor grades, while an inverse relationship was observed in most of the adenocarcinoma. Age was negatively associated with tumor grade in patients with esophageal adenocarcinoma, gastric adenocarcinoma, pancreatic adenocarcinoma and colorectal adenocarcinoma. Notably, patients with intra- and extra-hepatic cholangiocarcinoma did not show a positive association between age and tumor grade. In addition, possible interactions with sex and with race on the primary outcome was observed in four types of tumor (Table 3). We also observed better long-term prognoses for patients with well-differentiated tumors, which is consistent with results in previous studies.[3,5]

Previous studies have demonstrated the different clinicopathologic characteristics including tumor grade between younger and older patients with tumor. $[9,11,12]$ Several studies showed that younger patients tend to present with more histologically aggressive tumors.[12,13] However, there was no existed publications illustrating the independent association of age and tumor grade. In the current study, by using multivariable regression analyses and the smoothing plot method, we illustrated the association of age and tumor grade in 13 types of tumor. The results in the present study demonstrated that tumor occurred at different ages may have different molecular characteristics. Actually, many theories (e.g., accumulated mutations in the genome) have been proposed to explain the effects of age on human cells, tissues, and organs.[14] Puccini, et al. showed a significantly different mutation rates between younger and older patients in colorectal cancer.[15] Atyah, et al. also observed differences in gene mutations, copy number variants, and mRNA expressions in older and younger patients with hepatocellular carcinoma.[14] However, further studies are still needed to illustrate the mechanisms behind the phenomena observed in this study. In this study, the patterns of associations between age and tumor grade were different between adenocarcinoma and squamous cell carcinoma, which may be a reflection of the distinct molecular subtypes of these two types of tumor.

Admittedly, there are several limitations to this study. Like other researches based on SEER, the main drawback of the data from SEER is the lack of other specific clinicopathologic features, which may also influence the significance and effect of association between age and tumor grade. The second limitation is the lack of mechanisms related to the phenomena observed in this study. Further studies in the molecular level should be carried out to explain the results from the current study. Despite these limitations, in this study, we present a comprehensive study illustrating the effect of age on the tumor grade. The patterns of relationship between age and tumor grade were different in patients with different types of tumor (e.g., cholangiocarcinoma and hepatocellular carcinoma, and adenocarcinoma and squamous cell carcinoma). In addition, age and race had impact on the association of age and tumor grade in some types of tumor. Finally, we proved once again that higher tumor grade was related to poorer prognoses, which indicated that tumor grade can reflect the proliferation and aggressiveness of the tumor. To our knowledge, this is the first study on this topic. It contributes to the limited data available regarding the age-specific aspects of tumor patients, and supports the need to address potential differences in the diagnosis, treatment, and prognostic prediction of tumors in the younger and older patients.

\section{Abbreviations}

SEER: Surveillance, Epidemiology and End Results ICD-0-3: International Classification of Diseases for Oncology.

\section{Declarations}




\section{Ethics approval and consent to participate: This study is in accordance with the Declaration of Helsinki and has been approved by the Institutional Review Board at the West China Hospital. The data was retrieved after our application was approved by the SEER registry.}

\section{Consent for publication: Not applicable.}

Availability of data and material: All primary data is available by sending email to: zhangyangeplastic@126.com or downloading from SEER database.

Competing interests: The authors declare no competing interests.

Funding: None.

Author contributions: LW proposed the study; LW performed the research and wrote the first draft; LW and ZYG collected and analyzed the data; ZYG is the guarantor; all authors contributed to the design and interpretation of the study and to further drafts, and have read and approved the final version to be published.

Acknowledgements: None.

\section{References}

1. Flejou JF: [WHO Classification of digestive tumors: the fourth edition]. Annales de pathologie 2011, 31(5 Suppl):S27-31.

2. Chandler I, Houlston RS: Interobserver agreement in grading of colorectal cancers-findings from a nationwide web-based survey of histopathologists. Histopathology 2008, 52(4):494-499.

3. Alattar AA, Carroll KT, Bryant AK, Hirshman B, Joshi R, Carter BS, Harismendy O, Chen CC: Prognostic Importance of Age, Tumor Location, and Tumor Grade in Grade II Astrocytomas: An Integrated Analysis of the Cancer Genome Atlas and the Surveillance, Epidemiology, and End Results Database. World neurosurgery 2018.

4. Chen K, Zhang W, Zhang Z, He Y, Liu Y, Yang X: Simple Vascular Architecture Classification in Predicting Pancreatic Neuroendocrine Tumor Grade and Prognosis. Digestive diseases and sciences 2018, 63(11):31473152.

5. Hlavsa J, Cecka F, Zaruba P, Zajak J, Gurlich R, Strnad R, Pavlik T, Kala Z, Lovecek M: Tumor grade as significant prognostic factor in pancreatic cancer: validation of a novel TNMG staging system. Neoplasma 2018, 65(4):637-643.

6. Johncilla M, Chen Z, Sweeney J, Yantiss RK: Tumor Grade is Prognostically Relevant Among Mismatch Repair Deficient Colorectal Carcinomas. The American journal of surgical pathology 2018.

7. Martin SP, Ruff S, Diggs LP, Drake J, Ayabe RI, Brown ZJ, Wach MM, Steinberg SM, Davis JL, Hernandez JM: Tumor grade and sex should influence the utilization of portal lymphadenectomy for early stage intrahepatic cholangiocarcinoma. HPB : the official journal of the International Hepato Pancreato Biliary Association 2018.

8. Nasioudis D, Mastroyannis SA, Ko EM, Latif NA: Does tumor grade influence the rate of lymph node metastasis in apparent early stage ovarian cancer? Archives of gynecology and obstetrics 2018, 298(1):179- 
182.

9. Do SI, Lee HW, Sohn JH, Kim K: Clinicopathologic characteristics of young patients with gallbladder cancer. Pathology, research and practice 2017, 213(3):189-193.

10. Yang S, Li H, Jia C, Ma X, Guo W, Li H: Clinicopathological features and prognosis of patients <45 years old with esophageal adenocarcinoma comparing to other age groups. Journal of thoracic disease 2016, 8(10):2724-2729.

11. Kong X, Wang JL, Chen HM, Fang JY: Comparison of the clinicopathological characteristics of young and elderly patients with gastric carcinoma: a meta analysis. Journal of surgical oncology 2012, 106(3):346-352.

12. De B, Rhome R, Jairam V, Ozbek U, Holcombe RF, Buckstein M, Ang C: Gastric adenocarcinoma in young adult patients: patterns of care and survival in the United States. Gastric cancer: official journal of the International Gastric Cancer Association and the Japanese Gastric Cancer Association 2018, 21(6):889-899.

13. Wang R, Wang MJ, Ping J: Clinicopathological Features and Survival Outcomes of Colorectal Cancer in Young Versus Elderly: A Population-Based Cohort Study of SEER 9 Registries Data (1988-2011). Medicine 2015, 94(35):e1402.

14. Atyah M, Yin YR, Zhou CH, Zhou Q, Chen WY, Dong QZ, Ren N: Integrated analysis of the impact of age on genetic and clinical aspects of hepatocellular carcinoma. Aging 2018, 10(8):2079-2097.

15. Puccini A, Lenz HJ, Marshall JL, Arguello D, Raghavan D, Korn WM, Weinberg BA, Poorman K, Heeke AL, Philip PA et al: Impact of Patient Age on Molecular Alterations of Left-Sided Colorectal Tumors. The oncologist 2018.

\section{Figures}



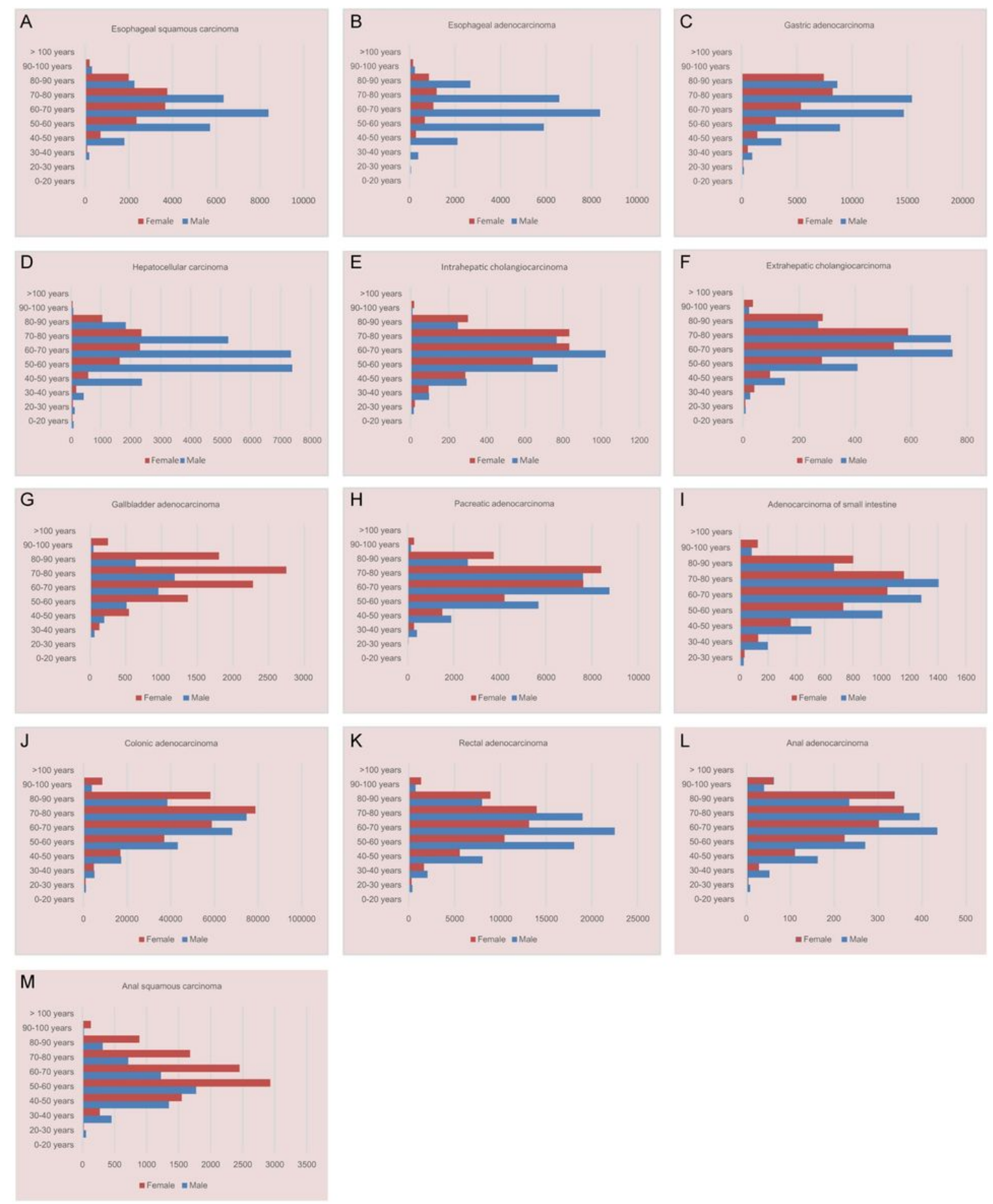

\section{Figure 1}

The number of patients with 13 types of tumor were shown by sex and age (age was divided into ten groups). A, Esophageal squamous carcinoma. B, Esophageal adenocarcinoma. C, Gastric adenocarcinoma. D, Hepatocellular carcinoma. E, Intrahepatic cholangiocarcinoma. F, Extrahepatic cholangiocarcinoma. G, Gallbladder adenocarcinoma. $\mathrm{H}$, Pancreatic adenocarcinoma. I, Adenocarcinoma of small intestine. J, Colonic adenocarcinoma. K, Rectal adenocarcinoma. L, Anal adenocarcinoma. M, Anal squamous carcinoma. 

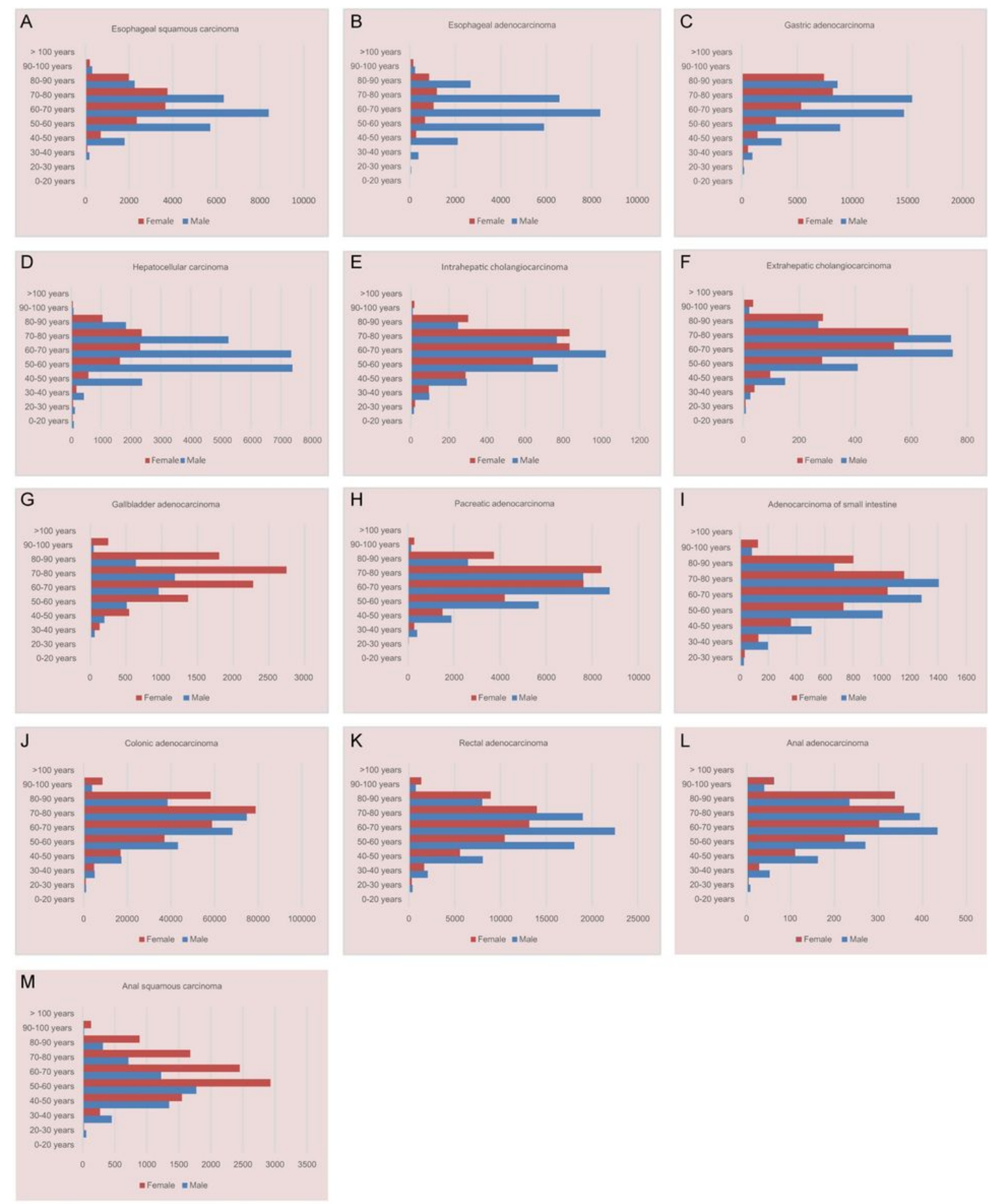

\section{Figure 1}

The number of patients with 13 types of tumor were shown by sex and age (age was divided into ten groups). A, Esophageal squamous carcinoma. B, Esophageal adenocarcinoma. C, Gastric adenocarcinoma. D, Hepatocellular carcinoma. E, Intrahepatic cholangiocarcinoma. F, Extrahepatic cholangiocarcinoma. G, Gallbladder adenocarcinoma. $\mathrm{H}$, Pancreatic adenocarcinoma. I, Adenocarcinoma of small intestine. J, Colonic adenocarcinoma. K, Rectal adenocarcinoma. L, Anal adenocarcinoma. M, Anal squamous carcinoma. 
A

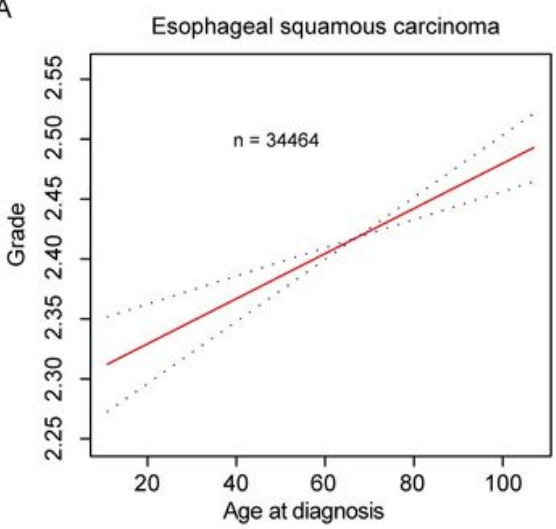

D

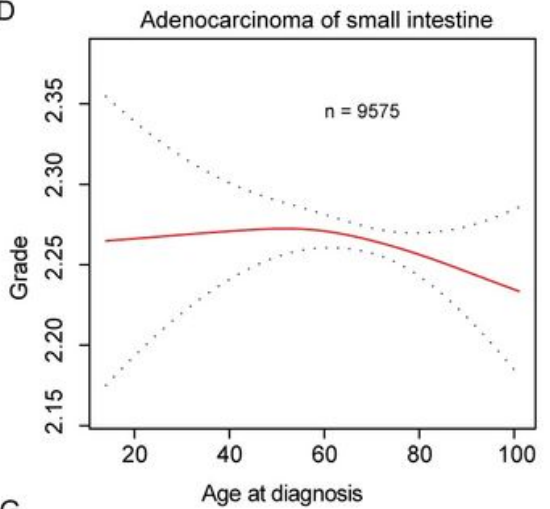

G

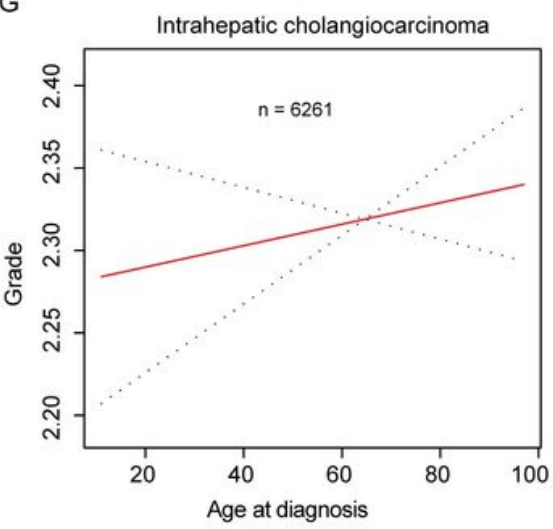

B

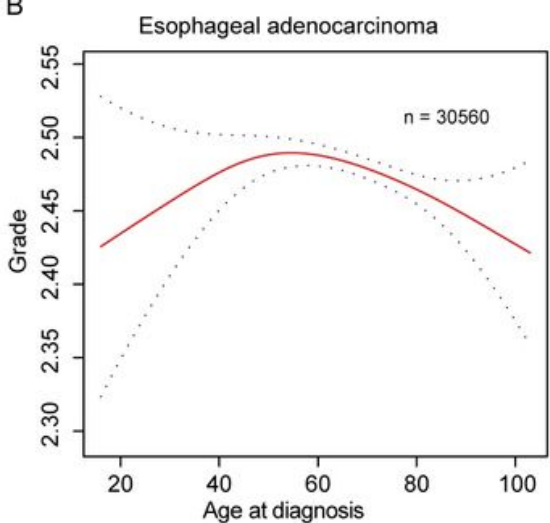

E

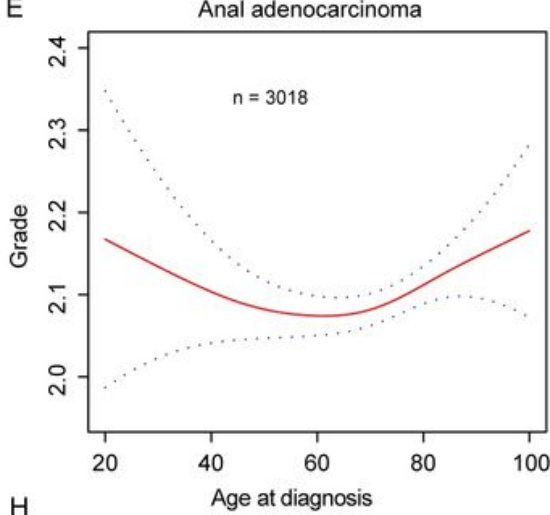

$\mathrm{H}$

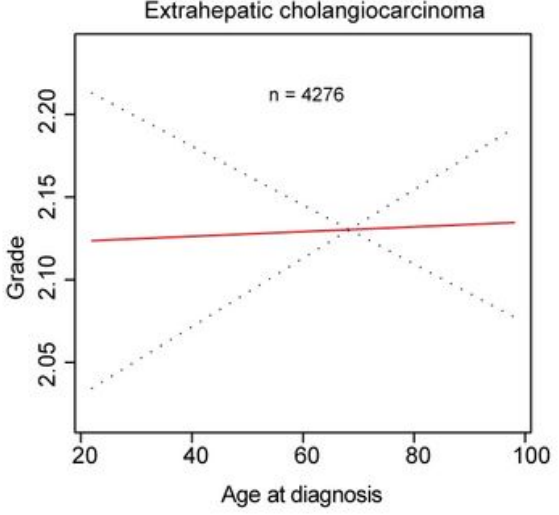

C

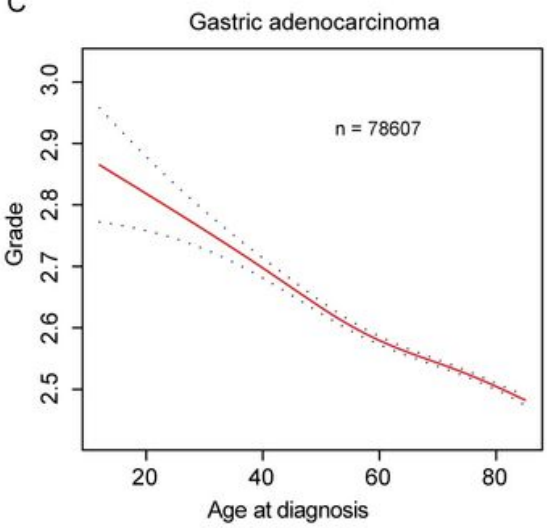

F
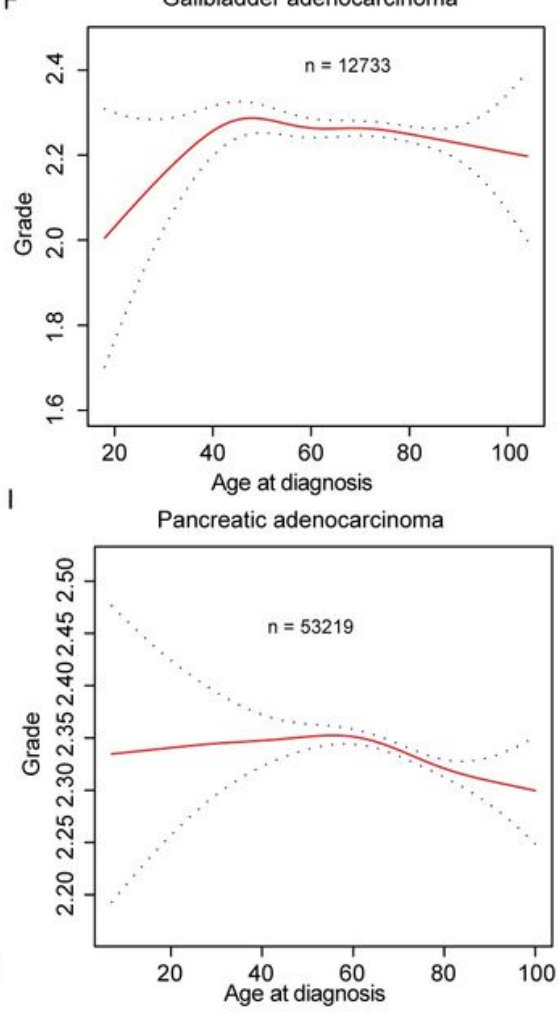

\section{Figure 2}

The smoothing plot showed the associations of age and tumor grade in nine types of tumor. A, Esophageal squamous carcinoma. B, Esophageal adenocarcinoma. C, Gastric adenocarcinoma, D, Adenocarcinoma of small intestine. E, Anal adenocarcinoma. F, Gallbladder adenocarcinoma. G, Intrahepatic cholangiocarcinoma. H, Extrahepatic cholangiocarcinoma. I, Pancreatic adenocarcinoma. In each smoothing plot, sex and race were adjusted. The dotted line: 95\% confidential interval. 
A

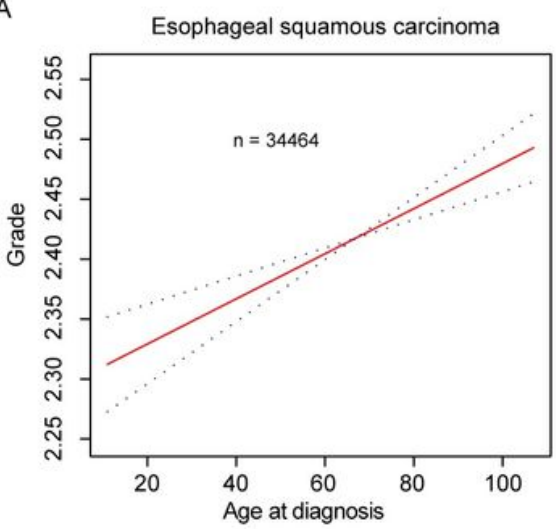

D

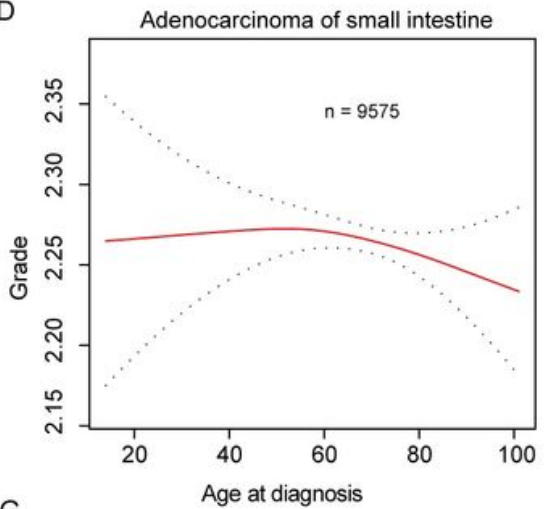

G

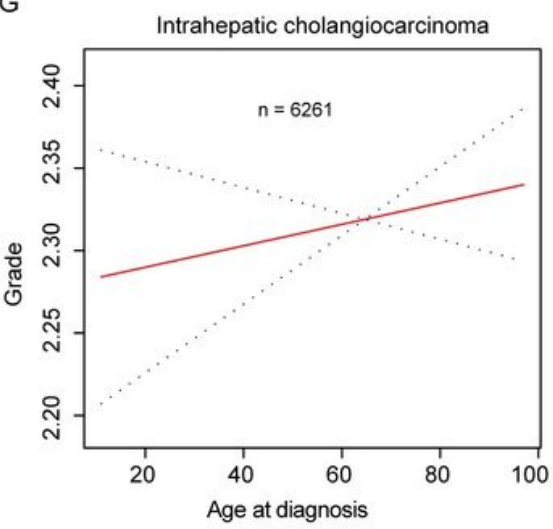

B

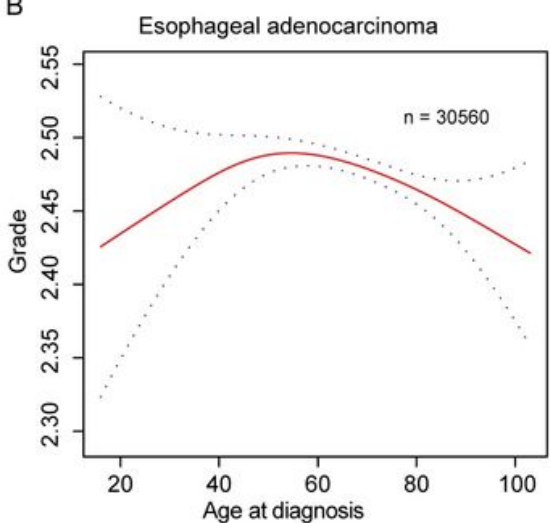

E

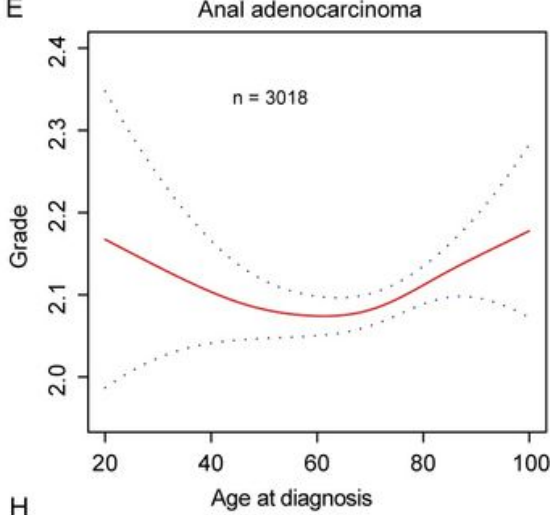

$\mathrm{H}$

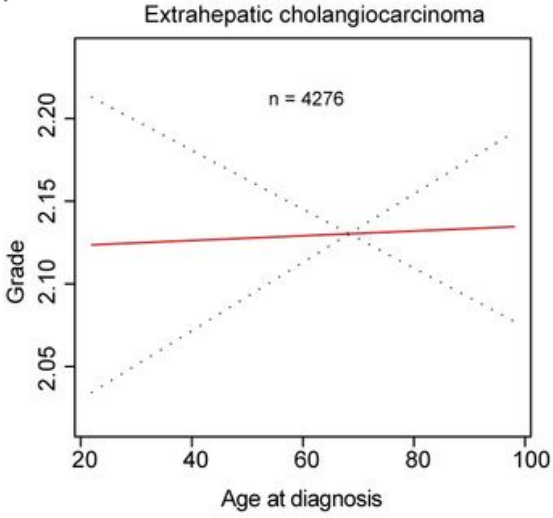

C

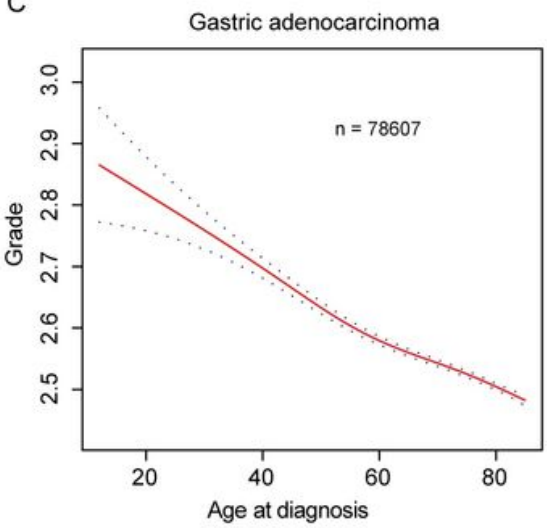

$\mathrm{F}$
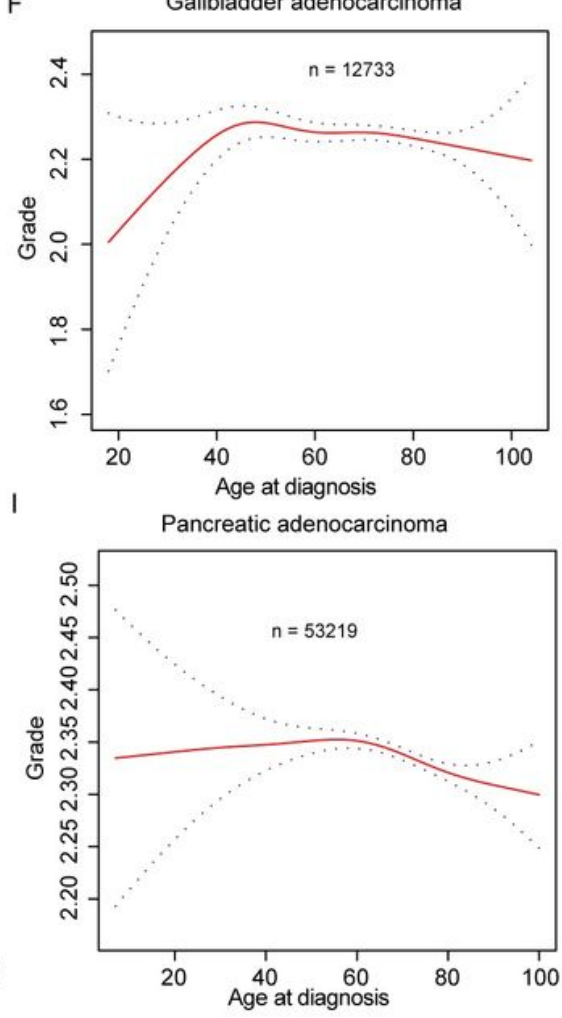

\section{Figure 2}

The smoothing plot showed the associations of age and tumor grade in nine types of tumor. A, Esophageal squamous carcinoma. B, Esophageal adenocarcinoma. C, Gastric adenocarcinoma, D, Adenocarcinoma of small intestine. E, Anal adenocarcinoma. F, Gallbladder adenocarcinoma. G, Intrahepatic cholangiocarcinoma. H, Extrahepatic cholangiocarcinoma. I, Pancreatic adenocarcinoma. In each smoothing plot, sex and race were adjusted. The dotted line: 95\% confidential interval. 

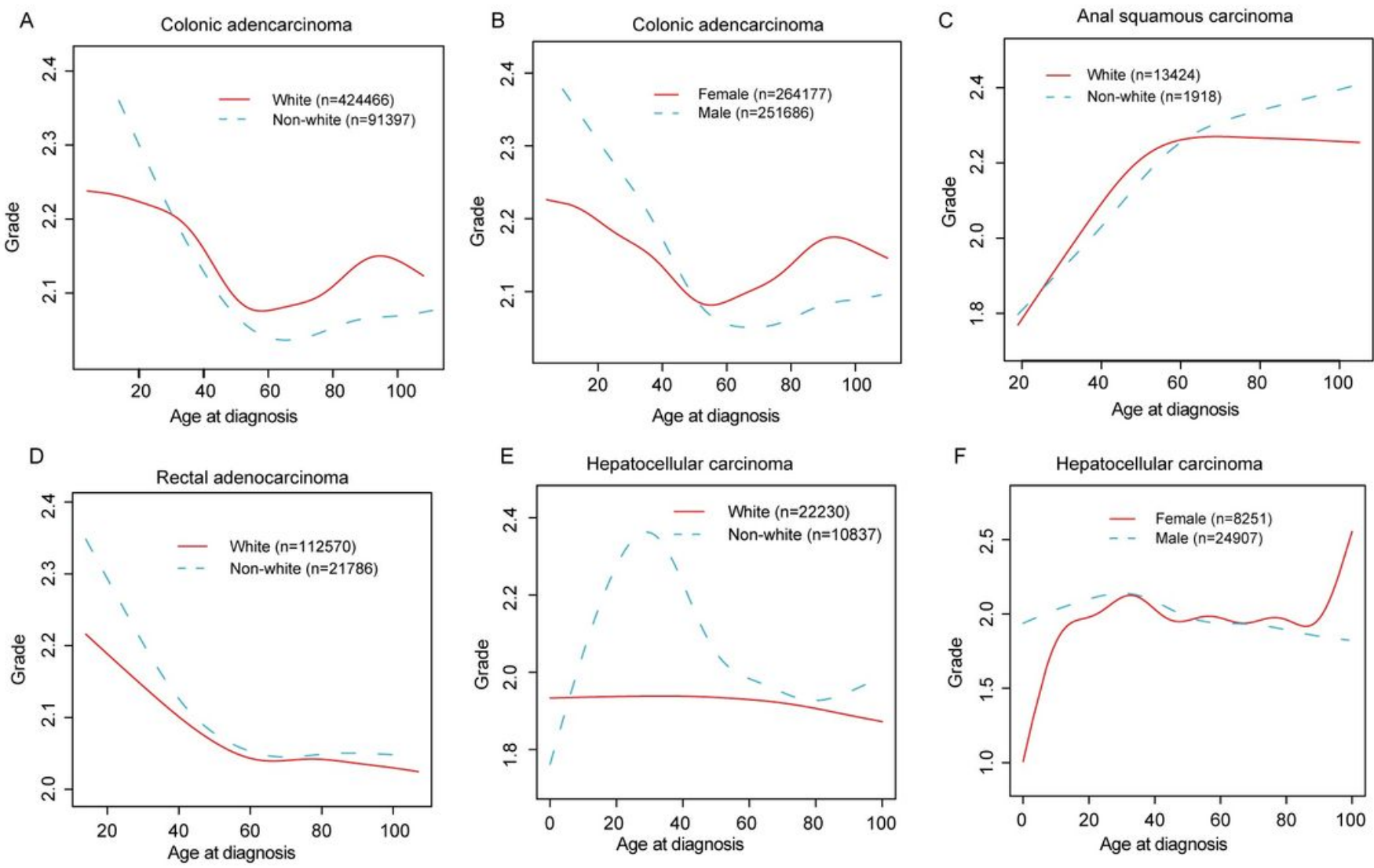

\section{Figure 3}

The smoothing plot showed the associations of age and tumor grade in subgroups (sex and race). A, Colonic adenocarcinoma classified by race. B, Colonic adenocarcinoma classified by sex. $C$, Anal squamous carcinoma classified by race. D, Rectal adenocarcinoma classified by race. E, Hepatocellular carcinoma classified by race. F, Hepatocellular carcinoma classified by sex. The interaction $P$ values of these four types of tumor were less than 0.05 in interaction test, thus subgroup analyses were performed based on corresponding interactive factors. 

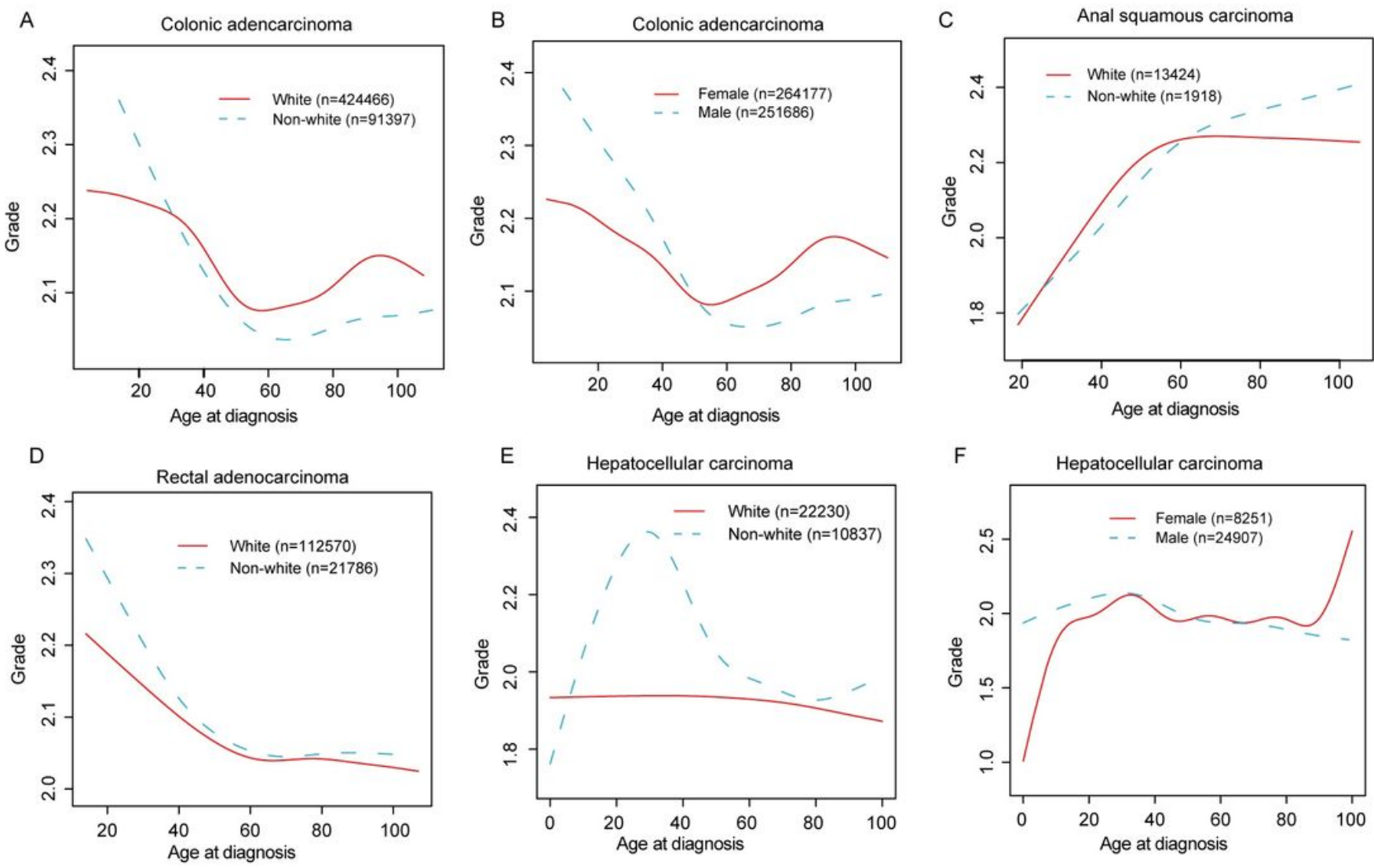

\section{Figure 3}

The smoothing plot showed the associations of age and tumor grade in subgroups (sex and race). A, Colonic adenocarcinoma classified by race. B, Colonic adenocarcinoma classified by sex. $C$, Anal squamous carcinoma classified by race. D, Rectal adenocarcinoma classified by race. E, Hepatocellular carcinoma classified by race. F, Hepatocellular carcinoma classified by sex. The interaction $P$ values of these four types of tumor were less than 0.05 in interaction test, thus subgroup analyses were performed based on corresponding interactive factors. 

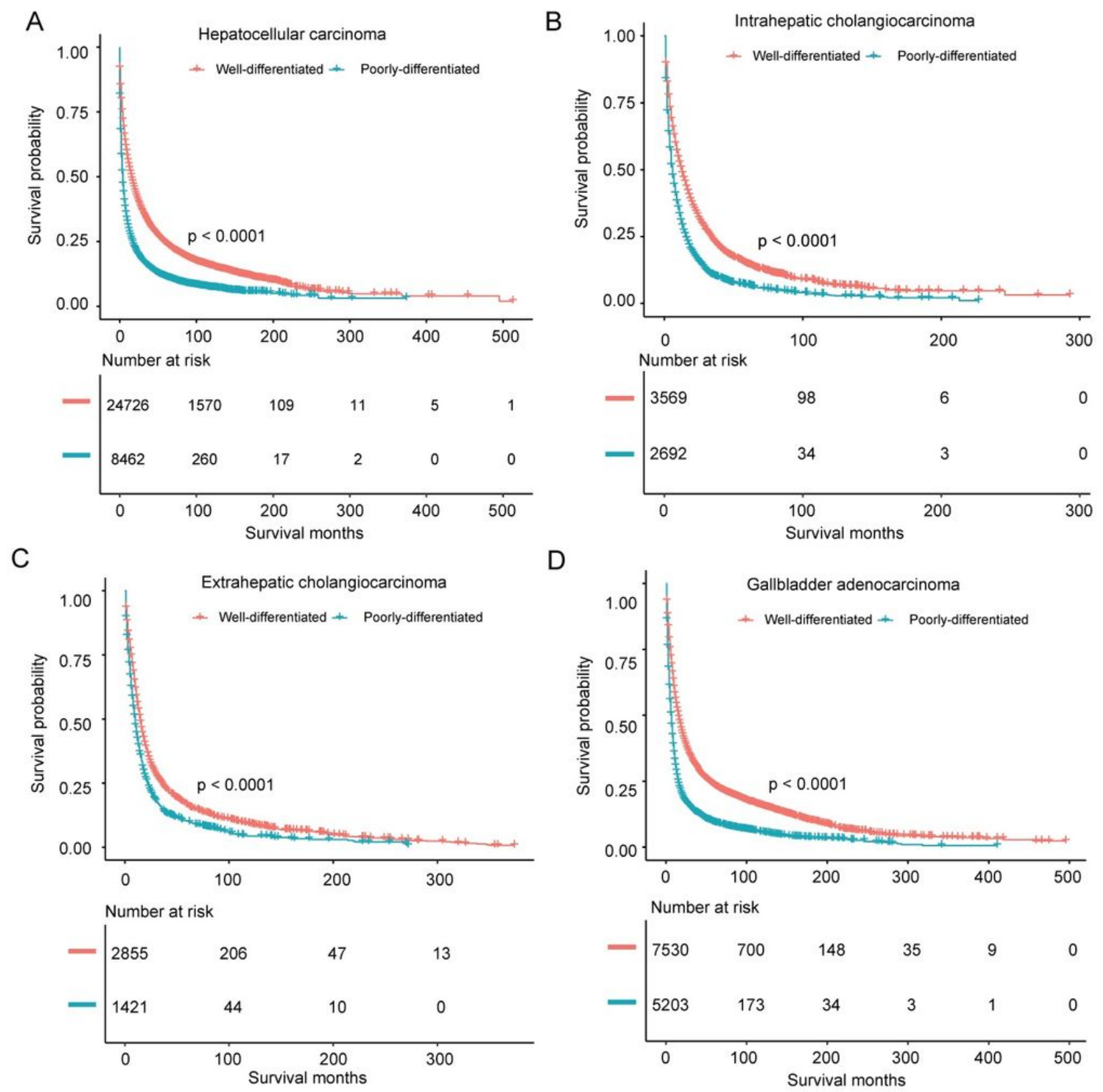

\section{Figure 4}

Survival analyses of four types of tumor in the hepatobiliary system according to tumor grade. A, Hepatocellular carcinoma. B, Intrahepatic cholangiocarcinoma. C, Extrahepatic cholangiocarcinoma. D, Gallbladder adenocarcinoma. 

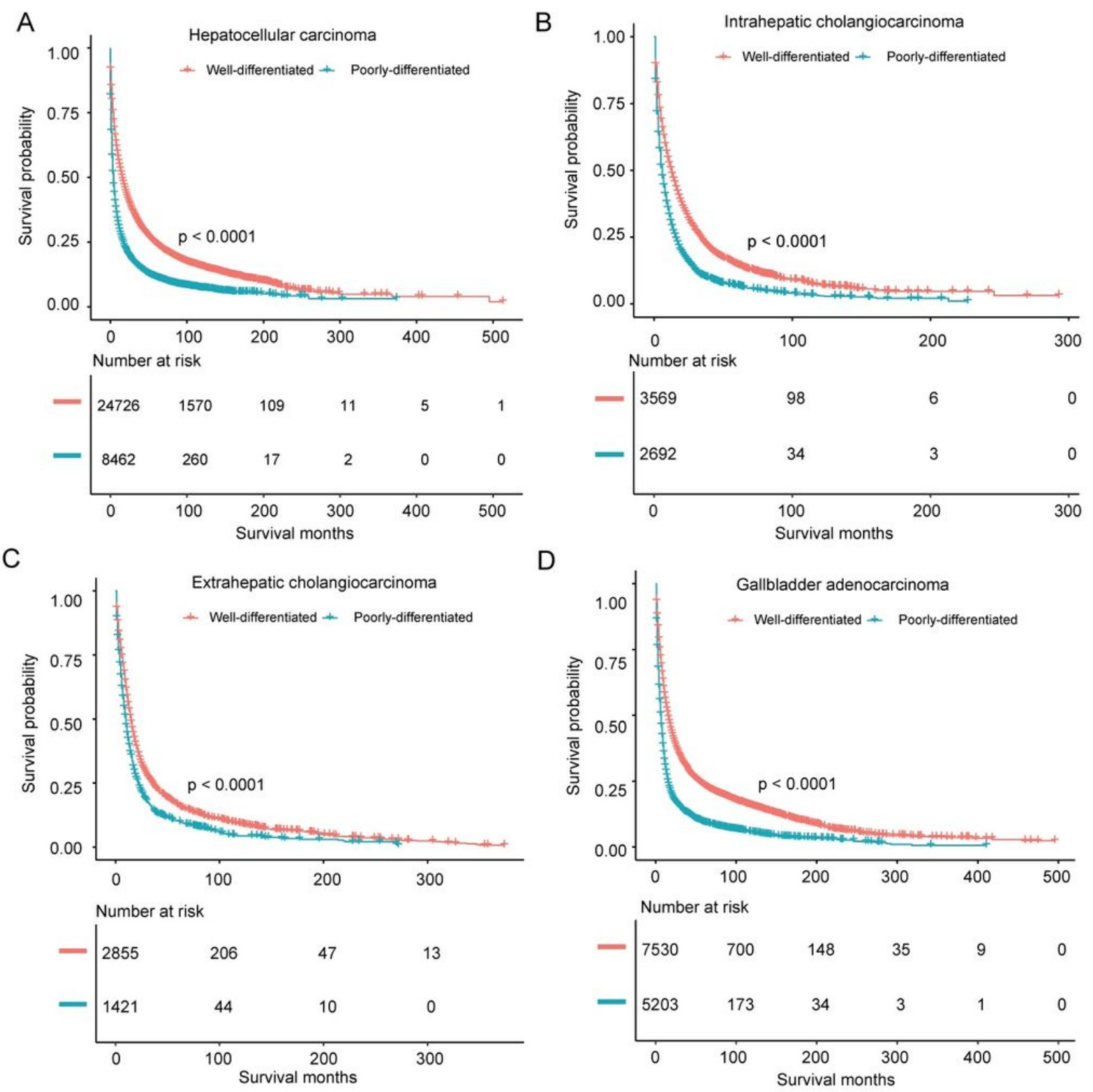

\section{Figure 4}

Survival analyses of four types of tumor in the hepatobiliary system according to tumor grade. A, Hepatocellular carcinoma. B, Intrahepatic cholangiocarcinoma. C, Extrahepatic cholangiocarcinoma. D, Gallbladder adenocarcinoma. 
A
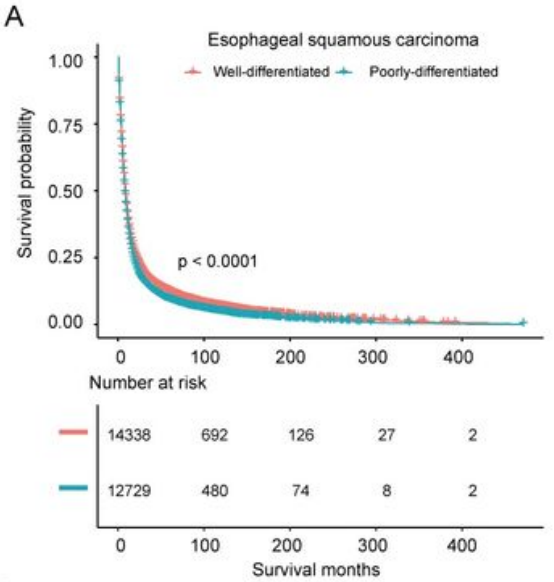

D

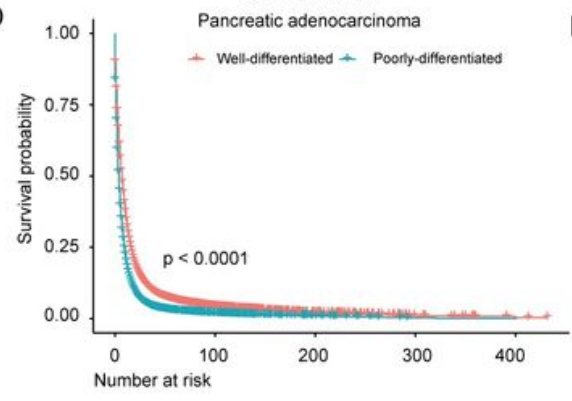

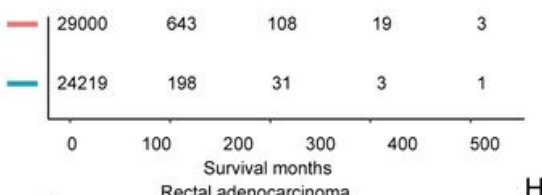

G

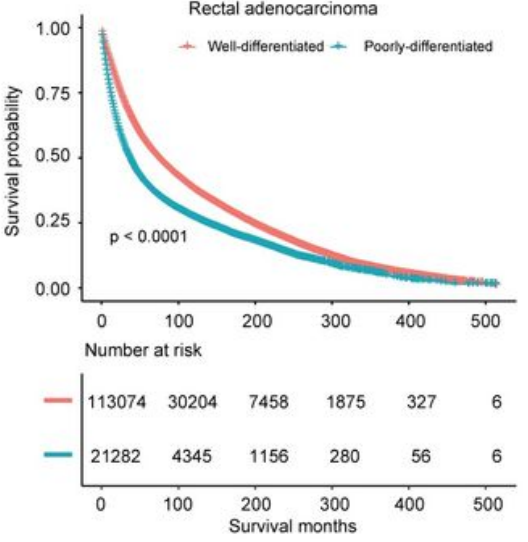

B
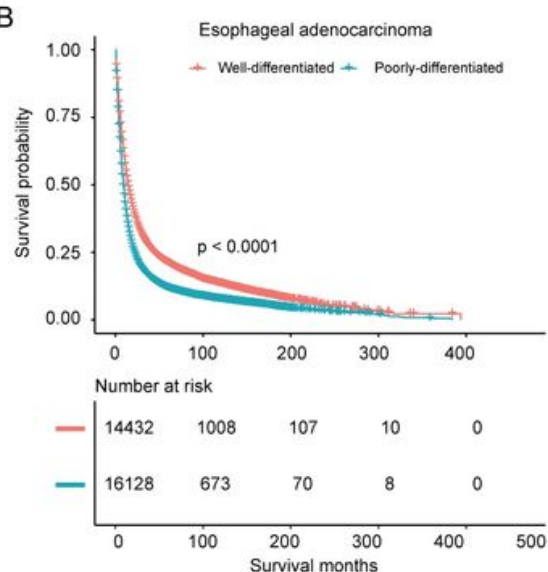

E
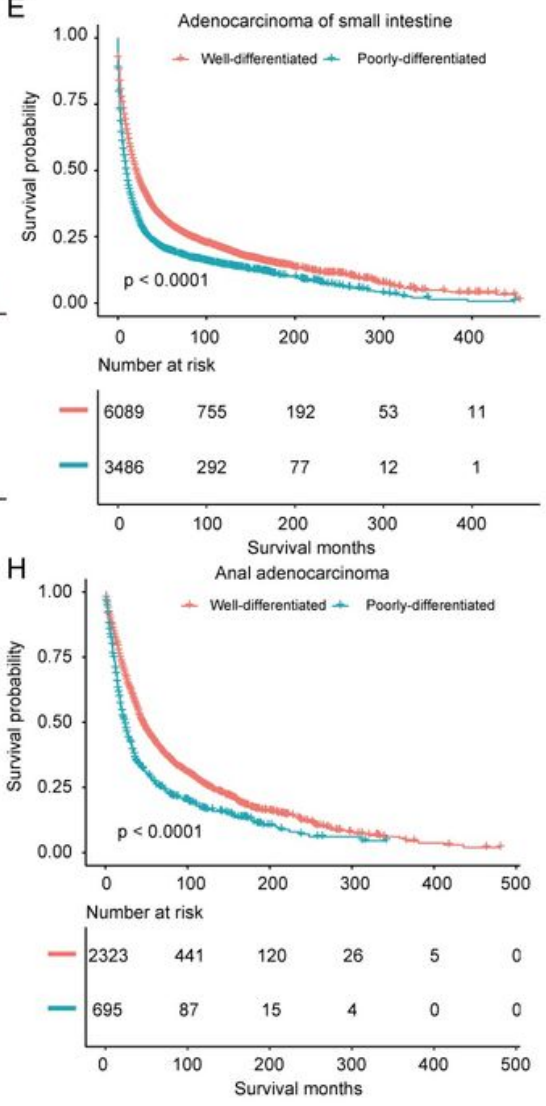

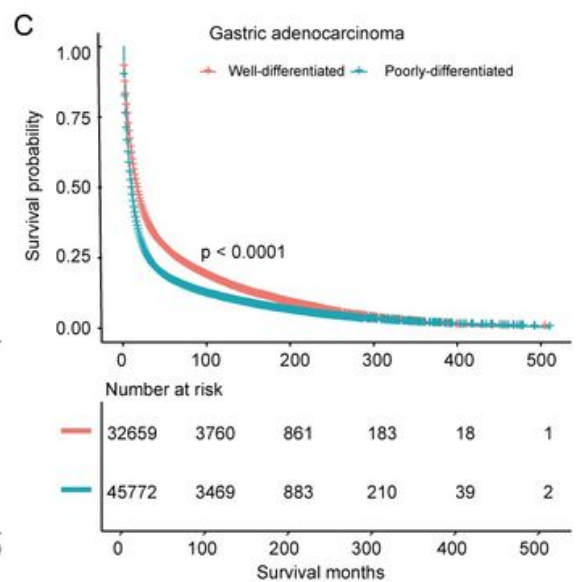

F 1.00

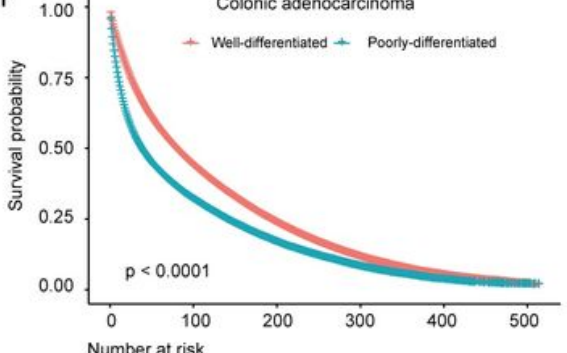

$-\mid \begin{array}{llllll}412602 & 116878 & 28677 & 6907 & 1123 & 21\end{array}$

$\begin{array}{llllll}103261 & 21630 & 5189 & 1212 & 244 & 11\end{array}$

I

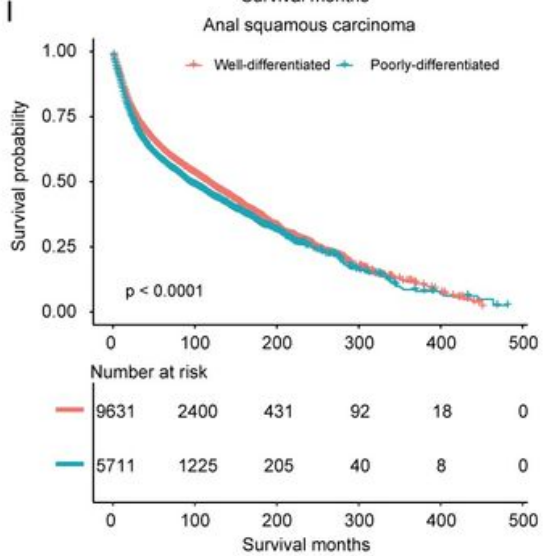

\section{Figure 5}

Survival analyses of nine types of tumor according to tumor grade. A, Esophageal squamous carcinoma. B, Esophageal adenocarcinoma. C, Gastric adenocarcinoma. D, Pancreatic adenocarcinoma. Hepatocellular carcinoma. E, Adenocarcinoma of small intestine. F, Colonic adenocarcinoma. G, Rectal adenocarcinoma. $\mathrm{H}$, Anal adenocarcinoma. I, Anal squamous carcinoma. 

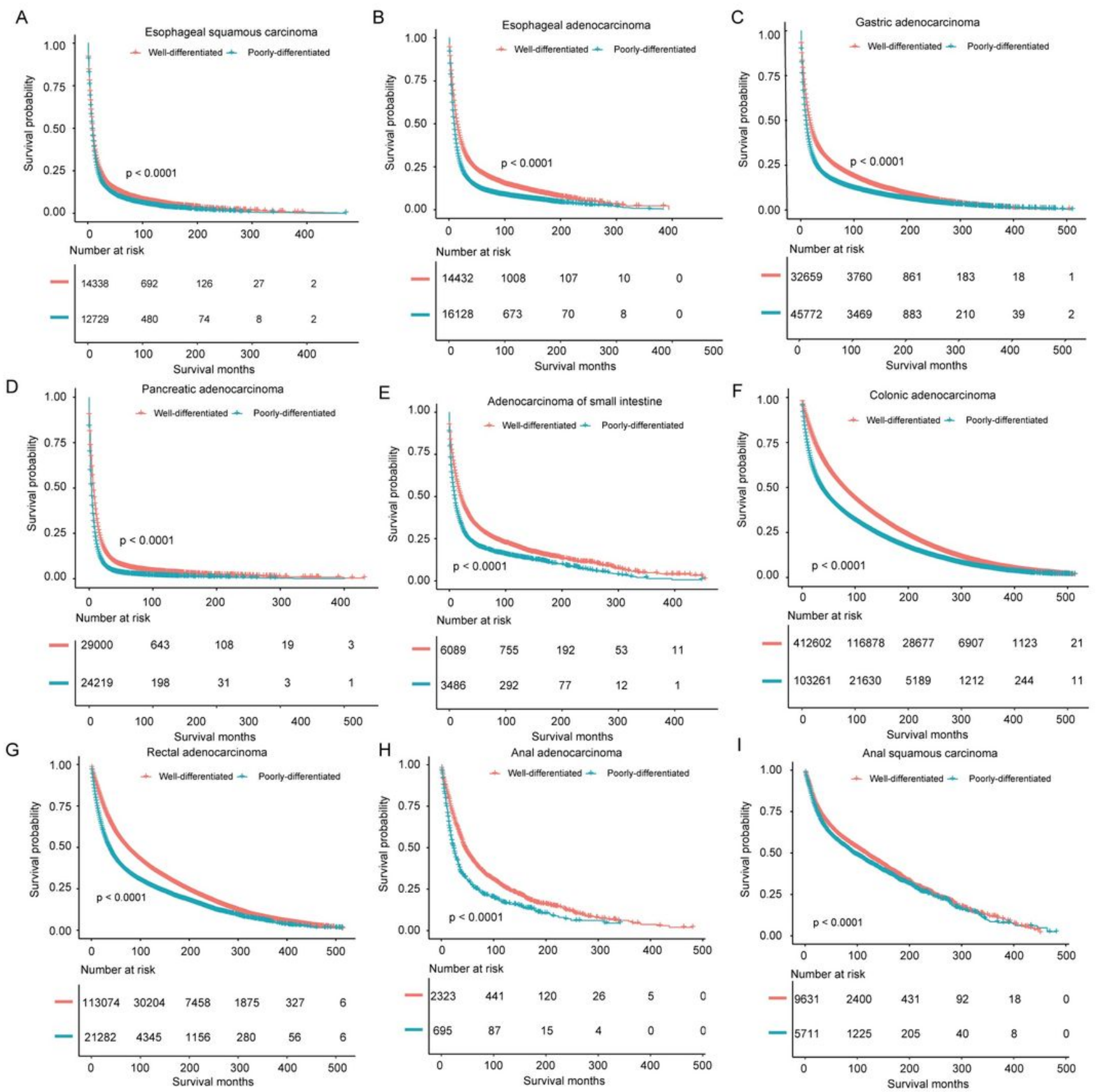

\section{Figure 5}

Survival analyses of nine types of tumor according to tumor grade. A, Esophageal squamous carcinoma. B, Esophageal adenocarcinoma. C, Gastric adenocarcinoma. D, Pancreatic adenocarcinoma. Hepatocellular carcinoma. E, Adenocarcinoma of small intestine. F, Colonic adenocarcinoma. G, Rectal adenocarcinoma. H, Anal adenocarcinoma. I, Anal squamous carcinoma.

\section{Supplementary Files}

This is a list of supplementary files associated with this preprint. Click to download. 
- SupplementaryTable1.docx

- SupplementaryTable1.docx 